\title{
A VÉGREHAJTÓ FUNKCIÓK ÉS AZ IMPLICIT TANULÁS VERSENGÖ KAPCSOLATA
}

\author{
VIRÁG MÁRTA ${ }^{1,2}$ - JANACSEK KAROLINA ${ }^{1,3}$ - NÉMETH DEZSŐ ${ }^{1,3}$ \\ ${ }^{1}$ Eötvös Loránd Tudományegyetem, Pszichológiai Intézet \\ ${ }^{2}$ Országos Klinikai Idegtudományi Intézet, Epilepszia Centrum \\ ${ }^{3}$ MTA TTK Kognitív Idegtudományi és Pszichológiai Intézet \\ E-mail: nemethd@gmail.com
}

Beérkezett: 2016. szeptember 2. - Elfogadva: 2016. szeptember 25.

\begin{abstract}
Jelen tanulmány különbözố neurokognitív folyamatok versengố kapcsolatát vizsgálja az implicit tanulás és a végrehajtó funkciók müködésének bemutatásán keresztül. Az implicit tanulásról ma már tudjuk, hogy - a végrehajtó funkciókat múködtetô frontális területekkel átfedésben - a fronto-striatális hálózat müködésén alapszik. Ez az átfedés egymással kooperáló és kompetitív folyamatokat is eredményezhet. Két kognitív folyamat versengő kapcsolatát többféle kísérleti elrendezésben is lehet vizsgálni, például az egyik folyamat gyengitésével vagy egy olyan vizsgálati populáció választásával, amelyben az egyik vagy a másik funkcióert felelôs agyi terület sérült. Jelen áttekintố tanulmány célja, hogy az utóbbi években megjelent, ezeket a módszereket használó kutatásokon keresztül bemutassa az implicit tanulás és a végrehajtó funkciók kapcsolatát. A felsorakoztatott eredmények alapján a frontális lebeny függó végrehajtó funkciók és az implicit tanulás között negatív kapcsolat áll fenn, tehát a gyengébb végrehajtó funkciók jobb implicit tanulási képességgel járhatnak együtt. Ennek a versengó kapcsolatnak a hátterében a felhasznált kognitív eröforrások átfedése állhat. A kognitív folyamatok interaktív szemlélete a kognitív funkciókat más funkciókkal való interakcióban vizsgálja, ami hozzájárulhat a pszichológiai funkciók jobb megértéséhez általában véve. Ez a szemléleti keret segithet az atipikus fejlődési mintázatok és kognitív nehézségek jobb megértésében és fejlesztố módszerek kidolgozásában.
\end{abstract}

Kulcsszavak: versengố neurokognitív folyamatok, implicit tanulás, végrehajtó funkciók, frontális lebeny 
Viselkedésünk adaptív módon történô igazításához az út a motoros, kognitív és társas készségeink formálódásán át vezet, amelyhez alapvetô fontosságú mechanizmus az implicit tanulás. Jól rámutat az implicit tanulás szerepére például az, ahogyan a fiatalabb generációk készségcsomagjához ma már hozzátartoznak a készségszintú számítógépes ismeretek is, ezek elsajátítása pedig szinte ugyanolyan gyorsan történik, mint a társas vagy a motoros készségeké. A folyamat nagy részben nem tudatos módon történik, ezért az ilyenfajta készségek fejlódését csak akkor realizáljuk, amikor már viselkedésünk szerves részeivé váltak. A tanulás nem tudatos része mellett fontosak azonban a kontrollált, több figyelmet igényló mechanizmusok is. Az automatikusabb és a kontrollált folyamatok kapcsolatának megértésében fontos kérdés, hogy azok egymást támogató, vagy inkább egymással versengô folyamatok-e. Az utóbbi évek kutatásai azt mutatják, hogy a két folyamat nemcsak egymást segíti, hanem bizonyos esetekben egymással versenghetnek is (Poldrack, Clark, Pare-Blagoev, Shohamy, Creso Moyano és Meyers, 2001).

Az emberi tanulás tudatos és nem tudatos mechanizmusok interakciójára épül. Az implicit, nem tudatos tanulás egy, a fronto-striatális hálózathoz köthetô (Doyon, Gaudreau, Laforce, Castonguay, Bedard és Bedard, 1997; Henke, 2010; Klivényi, Nemeth, Sefcsik, Janacsek, Hoffmann és Haden, 2012), alapvetôen szabályszerúségek nem tudatos módon való detektálására épülô tanulási folyamat (Reber, 1967). Implicit tanulást mérhetünk mesterséges nyelvtanulási feladattal (Miller, 1958), idôjóslási feladattal (Knowlton, Squire és Gluck, 1994) vagy implicit szekvencia tanulási feladattal (Howard és Howard, 1997), amely a fentebb felsoroltak közül az egyik leggyakrabban használt módszer. Az implicit tanulásnak ezen altípusa tisztán és átláthatóan mutatja meg az implicit tanulási folyamatokat, ezért ebben a tanulmányban fơként olyan eredményeket mutatunk be, amelyek ehhez a módszerhez köthetốek.

A frontális lebeny által vezérelt funkciókban is egyaránt hangsúlyos érintettsége az utóbbi években több olyan kutatást is inspirált, amelyek a végrehajtó funkciók és az implicit tanulás által közösen „használt” frontális hálózatokat hivatottak jobban feltárni, a közöttük lévô kapcsolatokat és ellentétes múködéseket jobban megérteni. Munakata és munkatársai (2012) a rugalmasabb viselkedés felé vezetô fejlődési átmenetnek, azaz a frontális lebeny érésének három különbözô állomását különböztették meg. Elôször, amikor a kognitív kontroll már elegendô stabilitással rendelkezik, reaktív módon le tud már küzdeni öröklött viselkedéses mintázatokat. Ezt követi a folyamat proaktív szakasza, amelyben a viselkedést a környezeti ingerek erôsen behatárolják, végül, a fejlôdés csúcsán pedig a környezettôl függetlenül, önvezérelten is képesek vagyunk saját viselkedésünk befolyásolására. Az ilyenfajta kognitív kontroll tehát egyértelmú elônyökkel jár az adaptív viselkedés kialakításában és a rugalmasság fenntartásában, azonban fontos megjegyezni, hogy ahogy előnyei, úgy hátrányai is vannak. Ezen a nyomvonalon elindulva Munakata és munkatársai egy késôbbi vizsgálatuk során (2014) megkülönböztették az erôsen múködô végrehajtó funkciók viselkedéses elônyeit és hátrányait. Kutatásaik eredményei alapján a fejlett végrehajtó funkciók elsôsorban a munkamemóriának és a célvezérelt viselkedés irányításának kedveznek. Ezek a konklúziók tovább mélyítik a végrehajtó funkciók és az implicit tanulási mechanizmusok közötti versengó szituáció megértését, miszerint átfedô kognitív források állnak a két funkció mögött, a kapcsolat iránya azonban még mindig nem teljesen világos. 
A neurokognitív versengés kutatásában korábban Poldrack és munkatársai (2008), valamint Filoteo és munkatársai is (2010) versengést mutattak ki különbözô neurokognitív folyamatok között. A frontális lebeny funkciók és az implicit tanulás versengô kapcsolatára az utóbbi idôben számos hazai kutatás is rámutatott (Janacsek, Fiser és Németh, 2012; Németh, Janacsek, Polner, és Kovács, 2013; valamint Virág, Janacsek, Horváth, Bujdosó, Fabó és Németh). Janacsek és munkatársai az implicit tanulási készség fejlốdési görbéjének bemutatásával járultak hozzá ehhez a kérdéshez (2012). Eszerint az implicit tanulás gyermekkorban a leghatékonyabb, késôbb pedig fokozatosan gyengül. Ennek egyik magyarázata az, hogy a frontális lebeny és a hozzáköthetô kognitív funkciók ontogenetikailag viszonylag késôn kezdik meg fejlôdésüket, addig is teret engedve más olyan funkciók fejlôdésének, mint például az implicit tanulás. Amint a fejlôdés során a frontális lebeny függó végrehajtó funkciók megerôsödnek, az implicit tanulási teljesítmény gyengül. Ezen eredményeket összefoglalva tehát úgy tûnik, hogy gyerekkorban az agy érzékenyebb a nyers valószínúségek befogadására (azaz dominánsabb a modellfüggetlen tanulás), a frontális lebeny fejlôdésével pedig egyre inkább az explicitebb szabályok irányába tolódik el (modellfüggố tanulás), ami gátolhatja a nyers valószínúségek feldolgozását. Az agy természetes fejlôdése során tehát „versengố agyi hálózatok” jöhetnek létre.

A versengés kérdésének megértéséhez egy lehetséges módszer az, ha a végrehajtó funkciók és az implicit tanulás közös forrását, jelenesetben a frontális lebeny múködését valamilyen módon manipuláljuk, miközben egy implicit szekvencia tanulási feladatot végeztetünk el a kísérleti személlyel (lásd az elsô alfejezetben). Egy másik lehetséges megközelítés a neuropszichológiai módszer, melyben a választott vizsgálati populáció végrehajtó funkciói sérültek, az implicit tanulási készség viszont megtartott. Iggy elkülöníthetôek a különbözô kognitív hálózatok (lásd a második alfejezetben).

\section{Az implicit tanulási folyamatok hipnózisban}

A „versengô agyi hálózatok” elméletébôl kiindulva Németh és munkatársai a hipnózis módszerét használták arra, hogy csökkentsék a frontális lebenyhez kapcsolható végrehajtó funkciók (például kontroll) és a fronto-striatális hálózat múködésén alapuló implicit tanulás közötti versengést (Németh, Janacsek, Polner és Kovács, 2013). A hipnózisos állapot fóként a frontális hálózatok gyengítésével vagy diszkonnekciójával (Kaiser, Barker, Haenschel, Baldeweg és Gruzelier, 1997; Kallio, Revonsuo, Hamalainen, Markela és Gruzelier, 2001; Egner, Jamieson, Gruzelier, 2005; Gruzelier, 2006; Wagstaff, Cole és Brunas-Wagstaff, 2007; Fingelkurts, Kallio és Revonsuo 2007; valamint Oakley és Halligan, 2009) visszafordítható változásokat okoz a kognitív feldolgozásban (Raz és Shapiro, 2002).

A vizsgálatban részt vevô kísérleti személyek magas hipnábilitás pontszámmal rendelkezó fiatal felnôttek közül kerültek ki. Az elvégzendó feladatok között egy implicit tanulási feladat, az Alternáló Szekvencia Tanulási Feladat (ASRT), valamint két végrehajtó funkciókat mérô feladat, a Wisconsin Kártyaszortírozási Feladat (WCST) és a Verbális Fluencia Feladat volt. Az implicit tanulási feladatot éber és hipnózis alatti állapotban is elvégezték a kísérleti személyek (Németh, 2013). 
Az eredmények egybevágnak azokkal a korábbi kutatási eredményekkel, amelyek a frontális lebeny funkciók és az implicit szekvenciatanulás között versengô kapcsolatot feltételeznek. Az eredmények azt mutatták, hogy a vizsgálati személyek jobban tanultak hipnózisban az éber kondícióhoz képest. A hipnózis frontális lebeny funkciókra gyakorolt hatását tovább tisztázandó, az éber és a hipnózis alatt tanuló kísérleti személyeket alacsony és magas végrehajtó funkció szerint is alcsoportokba osztották (1. ábra).

Ez az elemzés tehát tovább erôsítette a korábbi irodalomban leírt versengés meglétét, és jól rámutat ennek a vizsgálatnak a relevanciájára is. A magas végrehajtó funkciókkal rendelkezó kísérleti személyek tehát gyengébb implicit tanulási készséget mutattak az éber kondícióban a hipnózis kondícióhoz képest. Tehát a frontális agyi hálózatok és a hozzá kapcsolódó kognitív funkciók (például kontroll) múködésének módosulásával (jelen esetben hipnózis alkalmazásával) felszabadul az implicit tanulás számára is használatos, egyébiránt a végrehajtó funkciók által elfoglalt frontális erôforrás.

\section{Az implicit tanulás és a végrehajtó funkciók kapcsolatának neuropszichológiai vizsgálata}

Az implicit tanulás és a végrehajtó funkciók versengésének bizonyításához egy újabb vizsgálatban Virág és munkatársai (2015) frontális lebeny sérült személyek neuropszichológiai vizsgálatára fókuszáltak. Ehhez ideálisnak bizonyult az alkoholfüggóségben szenvedôk populációja, akiknél a frontális lebeny többé-kevésbé károsodott a hoszszabb távon fennálló rendszeres alkoholbevitel következményeként.

A vizsgálatban olyan, jól funkcionáló alkoholfüggó betegek vettek részt, akik a vizsgálat idején már legalább három hete absztinensek voltak. Viszonyításképpen melléjük korban és nemben illesztett egészséges kontrollcsoport került. Az elốzô vizsgálathoz hasonlóan a vizsgálati személyek implicit tanulási és végrehajtó funkciós képességeit mérték. A vizsgálati személyek végrehajtó funkciói a vártnak megfelelôen alakultak: az alkoholbeteg kísérleti személyek gyengébben teljesítettek a végrehajtó funkciókat mérô feladatokon az egészséges kontrollszemélyekhez képest. Ezzel szemben a két csoport nem mutatott szignifikáns különbséget implicit tanulás tekintetében, amely azt indikálja, hogy az alkoholizmus frontális lebenyre gyakorolt hatása nem volt szignifikáns hatással az implicit tanulási készségekre. Egy következô elemzés során az implicit tanulási feladaton elért teljesítményt korreláltatták a végrehajtó funkciókat méró feladatokon mért teljesítménnyel. Az elemzés az eddigi irodalommal és az elôzô hipnóziskutatással egybecsengô eredményt mutatott: a két funkció között egyértelmúen negatív együttjárás látszódott, amely akkor is stabilnak mutatkozott, amikor a kísérleti személyek csoportjain külön-külön (2. ábra, A és B) vagy egyben, minden személyt az elemzésbe véve (2. ábra, $\mathrm{C})$ vizsgálták. Tehát a gyengébb végrehajtó funkció erôsebb implicit tanulást eredményezett.

Az elôzô vizsgálathoz hasonlóan tehát ez a vizsgálat is a frontális lebeny funkciók és az implicit szekvencia tanulás között fennálló versengó kapcsolatot igazolja (Virág, 2015). 
A Erősebb végrehajtó funkciók

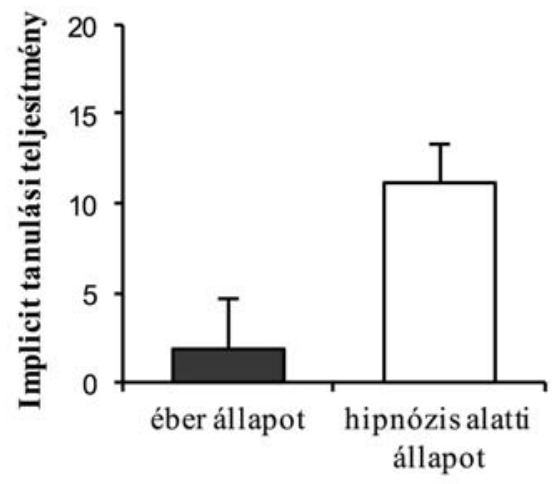

B Gyengébb végrehajtó funkciók

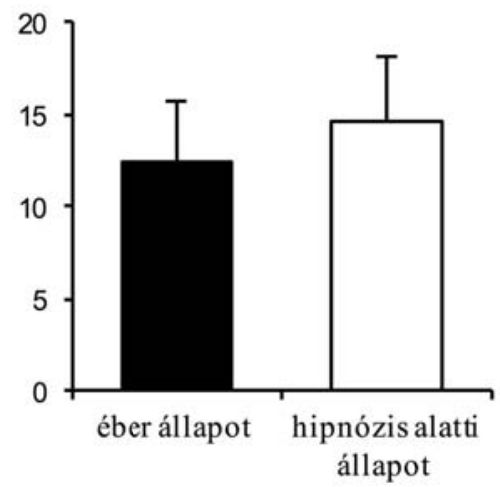

1. ábra. Németh és munkatársai (2013) alacsony és magas végrehajtó funkciók szerint két csoportba sorolták a kísérleti személyeket. Az erôs végrehajtó funkciókkal rendelkezô kísérleti személyek gyengébb implicit tanulást mutattak éber állapotban a hipnózis alatti állapothoz képest. Ez ugyanakkor nem volt elmondható az alacsony végrehajtó funkcióval rendelkezô kísérleti személyeknél, ôk ugyanis a kísérleti kondíciótól függetlenül hasonlóképpen teljesítettek. A hibasávok az átlag standard hibáját mutatják.

Az ábra átszerkesztve Németh és munkatársai, 2013, 3, 2. ábra alapján
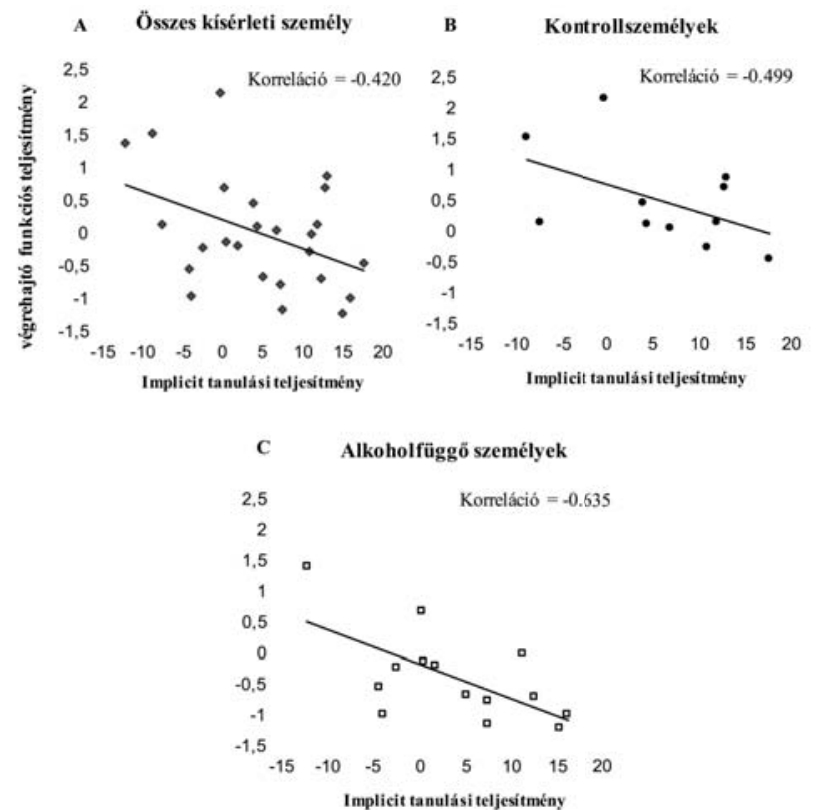

2. ábra. Virág és munkatársai (2015) eredményei ellentétes kapcsolatot mutatnak az implicit tanulás és a végrehajtó funkciók között. Ez a negatív korreláció megjelent a kontrollszemélyeknél (B), csak az alkoholbeteg kísérleti személyeket vizsgálva (C), és az összes kísérleti személyt egybe véve is (A). Összességében tehát a gyengébb végrehajtó funkció jobb implicit tanulási készséggel jár együtt. Az ábra átszerkesztve Virág és munkatársai, 2015, 6, 2. ábra alapján 
A „versengéselmélet” logikus értelmezési keretet nyújt a fent bemutatott vizsgálatok eredményeihez, miszerint a gyengébb frontális lebeny funkciók jobb implicit tanulási készségekkel járnak együtt. Ez összhangban van olyan elôzetes kutatási eredményekkel is, melyek szintén ellentétes irányú vagy versengó kapcsolatot találtak a frontális lebenyhez köthetố funkciók és az implicit tanulási folyamatok között. Munakata és munkatársai $(2012,2014)$ fejlôdési aspektusból vizsgálva azt találták, hogy az agyi és kognitív érés előrehaladtával a két funkció egyre inkább közös kognitív erôforrásért verseng. Az eredmények egybehangzanak Janacsek és munkatársainak (2012) eredményeivel is, a gyerekek implicit tanulási teljesítménye a frontális lebeny érésével és kognitív kontrollfunkciókban betöltött dominanciájának erôsödésével együtt párhuzamosan változnak.

A kísérleti pszichológiában és a kognitív idegtudományban újabban közkedvelt értelmezési keret a memóriafolyamatok interaktív szemlélete. Az utóbbi években több olyan vizsgálat is született, amelyek valamilyen második, az elsố memóriafeladattal interferáló feladatot adtak a kísérleti személyeknek, így a feladatokon nyújtott teljesítmény az interferencia mértékétôl függóen változott (Filoteo és mtsai, 2010; Poldrack és mtsai, 2001; Albouy, Sterpenich és Balteau, 2008). Fontos megjegyezni, hogy nem csak több feladat közötti interferencia tud hasonló helyzetet létrehozni az interaktív memóriarendszerek között. Közepes vagy nagyobb mértékú stressz is a frontális funkciók gyengüléséhez, és ezen keresztül kevesebb explorációhoz és erôsebb habituális (automatikusabb) viselkedéshez vezethet. Mindez azzal lehet összefüggésben, hogy a stresszel teli helyzetben a megnövekedett glükokortikoid mennyiség blokkolja a kogníció flexibilitását (frontális múködést) (Schwabe és Wolf, 2013). Ezekkel az eredményekkel összhangban vannak Borragán és Peigneux (2016) újabb kutatási eredményei is, miszerint a fáradás (kognitív kimerülés) pozitív hatással van az implicit tanulási képességekre. A magyarázat hasonló, mint az elôzőekben felsorolt kutatásoknál: a fáradás hatására a kognitív kontrollfolyamatok által lefoglalt erôforrások felszabadulnak, így azok az implicit tanulási folyamatokat tudják kiszolgálni. További kutatási lehetôségeket nyújthatnak a frontális lebenyt megcélzó repetitív transzkraniális stimulációs kutatások, konnektivitási kutatások vagy eltérô betegcsoportok neuropszichológiai vizsgálata is.

A fentebb felsorolt és ezekhez hasonló kutatások, amelyek a kognitív funkciókat más funkciókkal való interakcióban vizsgálják, sokat segíthetnek örökölt vagy fejlódési kognitív nehézségek megértésében, fejlesztésében. Ezen a nyomvonalon halad a frontális lebeny függó végrehajtó funkciók és a fronto-striatális hálózathoz kapcsolható implicit tanulás közötti kapcsolat mélyebb megértése, és az ezzel kapcsolatos kutatások is.

\section{Köszönetnyilvánítás}

A jelen tanulmányt az OTKA NF 105878-es számú pályázata támogatta. Janacsek Karolina Bolyai János Kutatói Ösztöndíjban részesült. 


\section{IRODALOM}

Albouy, G., Sterpenich, V., \& Balteau, E., (2008). Both the hippocampus and striatum are involved in consolidation of motor sequence memory. Neuron, 58, 261-272.

Blackwell, K. A., \& Munakata, Y. (2014). Costs and benefits linked to developments in cognitive control. Developmental Science, 17(2), 203-211.

Borragán, G., Slama, H., Destrebecqz, A., \& Peigneux, P. (2016). Cognitive Fatigue Facilitates Procedural Sequence Learning. Frontiers in Human Neuroscience, 10, 86.

Doyon, J., Gaudreau, D., Laforce, R., Castonguay, M., Bedard, P. J., Bedard, F., \& Bouchard, J. P. (1997) Role of the striatum, cerebellum, and frontal lobes in the learning of a visuomotor sequence. Brain and Cognition, 34, 218 -245.

Egner, T., Jamieson, G., \& Gruzelier, J. (2005). Hypnosis decouples cognitive control from conflict monitoring processes of the frontal lobe. Neuroimage, 27, 969-978.

Filoteo, J. V., Lauritzen, S., \& Maddox, W. T. (2010). Removing the Frontal Lobes. Psychological Science, 21, 415-423.

Fingelkurts, A. A., Kallio, S., \& Revonsuo, A. (2007). Cortex functional connectivity as a neurophysiological correlate of hypnosis: an EEG case study. Neuropsychologia, 45, 1452-1462.

Gruzelier, J. H. (2006). Frontal functions, connectivity and neural efficiency underpinning hypnosis and hypnotic susceptibility. Contemporary Hypnosis, 23, 15-32.

Henke, K. (2010). A model for memory systems based on processing modes rather than consciousness. Nature Reviews Neuroscience, 11, 523-532.

Howard, J. H., Jr., \& Howard, D. V. (1997) Age differences in implicit learning of higher-order dependencies in serial patterns. Psychology and Aging, 12, 634-656.

Janacsek, K., Fiser, J., \& Nemeth, D. (2012). The best time to acquire new skills: age-related differences in implicit sequence learning across the human lifespan. Developmental Science, 15(4), 496-505.

Kaiser, J., Barker, R., Haenschel, C., Baldeweg, T., \& Gruzelier, J. H. (1997). Hypnosis and eventrelated potential correlates of error processing in a stroop-type paradigm: a test of the frontal hypothesis* 1. International Journal of Psychophysiology, 27, 215-222.

Kallio, S., Revonsuo, A., Hamalainen, H., Markela, J., \& Gruzelier, J. (2001). Anterior brain functions and hypnosis: a test of the frontal hypothesis. International Journal of Clinical and Experimental Hypnosis, 49, 95-108.

Klivényi, P., Nemeth, D., Sefcsik, T., Janacsek, K., Hoffmann, I., Haden, G. P., \& Vecsei, L. (2012). Cognitive functions in ataxia with oculomotor apraxia type 2. Frontiers in Neurology, 3, 125.

Knowlton, B. J., Squire, L. R., \& Gluck, M. A. (1994). Probabilistic classification learning in amnesia. Learning E Memory, 1(2), 106-120.

Miller, G. A. (1958). Free recall of redundant strings of letters. Journal of Experimental Psychology, $56(6), 485$.

Munakata, Y., Snyder, H. R., \& Chatham, C. H. (2012). Developing cognitive control three key transitions. Current Directions in Psychological Science, 21(2), 71-77.

Nemeth, D., Janacsek, K., Polner, B., \& Kovacs, Z. A. (2013). Boosting human learning by hypnosis. Cerebral Cortex, 23(4), 801-805.

Oakley, D. A., Halligan, P. W. (2009). Hypnotic suggestion and cognitive neuroscience. Trends in Cognitive Sciences, 13, 264-270.

Poldrack, R., Clark, J., Pare-Blagoev, E. J., Shohamy, D., Creso Moyano, J., Meyers, C., \& Gluck, M. A. (2001). Interactive memory systems in the human brain. Nature, 414, $546-550$.

Raz, A., \& Shapiro T. (2002). Hypnosis and neuroscience: a cross talk between clinical and cognitive research. Archives of General Psychiatry, 59, 85-90. 
Reber, A. S. (1967). Implicit learning of artificial grammars. Journal of Verbal Learning and Verbal Behavior, 6(6), 855-863.

Schwabe, L., \& Wolf, O. T. (2013). Stress and multiple memory systems: from 'thinking' to 'doing'. Trends in Cognitive Sciences, 17(2), 60-68.

Virag, M., Janacsek, K., Horvath, A., Bujdoso, Z., Fabo, D., \& Nemeth, D. (2015). Competition between frontal lobe functions and implicit sequence learning: evidence from the long-term effects of alcohol. Experimental Brain Research, 1-9.

Wagstaff, G. F., Cole, J. C., \& Brunas-Wagstaff, J. (2007). Effects of hypnotic induction and hypnotic depth on phonemic fluency: a test of the frontal inhibition account of hypnosis. International Journal of Psychology and Psychological Therapy, 7, 27-40.

\title{
COMPETITION BETWEEN EXECUTIVE FUNCTIONS AND IMPLICIT LEARNING
}

\author{
VIRÁG, MÁRTA - JANACSEK, KAROLINA - NÉMETH, DEZSÔ
}

\begin{abstract}
This review demonstrates the competitive nature of different neurocognitive processes by focusing on the relationship between implicit learning and executive functions. Implicit learning mainly relies on fronto-striatal networks of the brain, while the cognitive resources of executive functions are based in frontal areas, hence indicating an overlap between the brain areas responsible for the two functions. This overlap could result in cooperative and competitive processes. Investigation of two cognitive functions such as implicit learning and executive functions can be based on different approaches: either by repressing one out of the two cognitive functions or by choosing an experimental population for which a brain region associated with one of the two cognitive functions is damaged or distorted. In the past couple of years, a great number of studies have shown the competitive nature of the two cognitive functions rooting from the above-mentioned approaches. Based on their results, one can conclude that weaker frontal lobe functions can lead to better implicit learning, which is presumably caused by the overlapping cognitive resources of the two functions. This interactive view of cognitive functions explains such processes as dependent on each other, which can lead us to a more thorough understanding of psychological functions in general. This conceptual framework can help in exploring and understanding atypical developmental patterns and other types of cognitive difficulties, and also in developing more effective rehabilitation methods.
\end{abstract}

Keywords: competitive neurocognitive processes, implicit learning, executive functions, frontal lobe 